\title{
Businesses Named After Founders Enjoy Greater Returns
}

\author{
Sharon Belenzon (Duke University, Fuqua School of Business)
}

KEYWORDS: Entrepreneurship, Leadership, Family Business.

\section{By Sharon Belanzon, Aaron K. Chatterji and Brendan Daley}

Business history is filled with legendary companies named for their founders: Hewlett-Packard, Procter \& Gamble, Johnson \& Johnson, McKinsey and Co. Some of these firms have gone through several transitions in ownership but preserved the original name that is associated with their image and reputation. Many consultants, marketing experts and books have advised companies on the pros and cons of naming themselves after a person, and some say that a self-named business conveys a lack of creativity and might reduce sales value. What does the research indicate?

Our study provides some answers. It suggests that new entrepreneurs may gain an edge if they name their businesses after themselves, especially if they have confidence in their abilities.

We analyzed 1.8 million European firms between 2002-2012. The results, published in a paper entitled "Eponymous Entrepreneurs," (https://www.aeaweb.org/articles?id=10.1257/aer.2014 1524) found that firms named after their owners enjoyed, on average, a 3 percent boost to their Return on Assets over firms that were not.

Other insights from our research:

- If an entrepreneur with a self-named business goes on to start other businesses without his or her own name, the subsequent businesses enjoyed a greater return than businesses started by other entrepreneurs who never named a business after themselves.

- Interestingly, firms that bore the surname of someone other than the owner did not perform as well as eponymous firms. The link between the owner's name and the business name matters.

- High-ability entrepreneurs were more likely to put their own names on the business. This sends a signal to the market that the founders are confident they will succeed, in turn increasing the market's confidence in their endeavor and thus actually helping them succeed.

- Naming the business for the owner is a calculated risk because if the business tanks so does the reputation of the owner.

- Note, however, owners who choose not to name the firm after themselves may signal lack of confidence in their own abilities.

- Entrepreneurs with rare last names are less likely to name their businesses after themselves, but the potential risks and rewards are greater if they do, because they are more strongly identified with their firms.

Our research team looked at data from the 1.8 million firms across Europe, in businesses such as real estate, business services, wholesale trade/durable goods and other markets. We studied an average of four years of data for each firm: names, financial information, and ownership structure/equity stakes. About 19 percent of these firms were named after their founders or owners. Using complex models, economics, social sciences and even game theory, we analyzed the information and found the link between eponymous firms and higher performance.

The takeaway: entrepreneurs can gain an edge when they name current and future businesses after themselves. However, they might consider the issues described above when choosing the name.

"We propose that naming the firm, specifically via eponymy, is one mechanism entrepreneurs may use to signal unique skills or high ability - an especially 
important consideration for new ventures," our research paper concludes.

\section{References}

Belenzon, Sharon, Aaron K. Chatterji, and Brendan Daley. 2017. "Eponymous Entrepreneurs." (https://www.aeaweb.org/articles?id=10.1257/aer.2014 1524) American Economic Review, 107 (6): 1638-55.

Additional Search Terms: business names, what to name my business, startups, naming my startup 